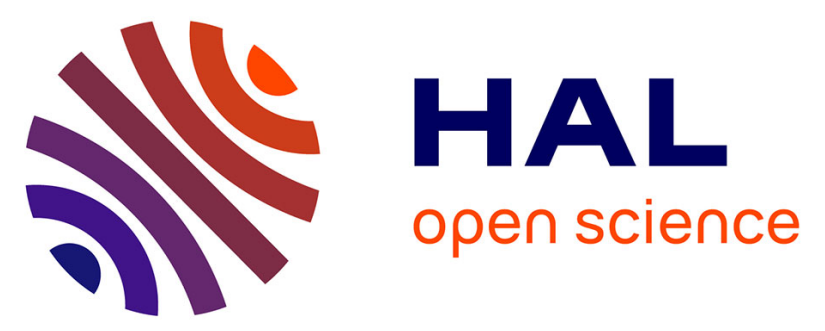

\title{
The Maintenance Function in the Context of Corporate Sustainability: A Theoretical-Analytical Reflexion
}

\author{
José De Souza, José Benedito Sacomano, Sergio Luiz Kyrillos, Francisco \\ Santos Milreu, Fabio Paparlado
}

\section{- To cite this version:}

José De Souza, José Benedito Sacomano, Sergio Luiz Kyrillos, Francisco Santos Milreu, Fabio Paparlado. The Maintenance Function in the Context of Corporate Sustainability: A TheoreticalAnalytical Reflexion. IFIP International Conference on Advances in Production Management Systems (APMS), Sep 2014, Ajaccio, France. pp.222-229, 10.1007/978-3-662-44736-9_27 . hal-01387870

\author{
HAL Id: hal-01387870 \\ https://hal.inria.fr/hal-01387870
}

Submitted on 26 Oct 2016

HAL is a multi-disciplinary open access archive for the deposit and dissemination of scientific research documents, whether they are published or not. The documents may come from teaching and research institutions in France or abroad, or from public or private research centers.
L'archive ouverte pluridisciplinaire HAL, est destinée au dépôt et à la diffusion de documents scientifiques de niveau recherche, publiés ou non, émanant des établissements d'enseignement et de recherche français ou étrangers, des laboratoires publics ou privés.

\section{(c)(1)}

Distributed under a Creative Commons Attribution| 4.0 International License 


\title{
The maintenance function in the context of corporate sustainability: a theoretical-analytical reflexion
}

\author{
José Barrozo de Souza ${ }^{1}$, José Benedito Sacomano ${ }^{1}$, Sergio Luiz Kyrillos ${ }^{1}$, Francisco \\ José Santos Milreu ${ }^{1}$, Fabio Paparlado ${ }^{2}$ \\ ${ }^{1}$ Paulista University-UNIP, Graduate Program in Production Engineering, Dr. Bacelar St. \\ 1212, São Paulo, Brazil \\ ${ }^{1}$ Espírito Santo Federal Institute - IFES, School Engineering, Vitória St. 1729, Vitória, \\ Brazil \\ \{José Barrozo de Souza, barrozo.pgep.ifes@gmail.com\}
}

\begin{abstract}
The paper presents an analytical reflection, based on the context of knowledge management, risk management, quality management, intra-organizational relationships through attributes associated with corporate sustainability. For reasons of theoretical essay, research was supported in mapping the primary references and analysis of different interpretations of sustainability reports from companies associated with the Ethos Institute (Brazil). This paper presents a reflective approach to assess the importance of integration between the maintenance and production, considering some attributes of corporate sustainability.
\end{abstract}

Keywords: Environmental 1, Operations 2, Production 3.

\section{Introduction}

\subsection{The background and purpose of this study}

The term "sustainable development" was popularized by the publication of the report Our Common Future in 1987 [1]. Although sustainable development is a social concept, is increasingly being applied as a corporate concept under the name of "Corporate Sustainability" [2]. Several authors have questioned whether sustainable development actually applies to the corporate level [3].

In particular, firms as actors in society have been pressed to change the way they do business to integrate the principles of sustainability into their everyday business practices and promote their impacts and contributions to sustainable development [4]. Thus arose alternative to the maximization of financial profit captured in phrases like "triple bottom line", where the criteria of economic, social and environmental performance must be integrated [5].

The urgency and magnitude of the threats and risks to global sustainability, together with its opportunities, will transform the disclosure of sustainability and transparency in a key success factor for any company [6]. In his lecture of the day 22/05/2013, titled "From Dilution is the Solution to Pollution to Regional Sustainable Development is the Solution for improved Quality of Life for All: The Long and 
Challenging Journey", 4rd International Workshop on Advances in Cleaner Production held in São Paulo, Brazil, in 2013, the chief editor of the Journal of Cleaner Production, Donald Huisingh urged "global sustainability as the Third Industrial Revolution".

With a growing social demand of corporate sustainability, companies embrace the strategic importance of environmental management practices for competitive advantage. Furthermore, firms tend to increase their market value when they announce that they are adopting environmental management systems such as ISO 14001 [7].

The promotion of sustainable development mission has been shaping the practice of all sectors of activity, for example, including the development of housing for sustainable practice, working to balance the economic, social and environmental performance [8]. Current studies indicate a need to integrate environmental management with the manufacturing strategy, including some themes, such as crossfunctional integration, environmental impact and waste reduction [9a].

Reliable information on the operational availability of production systems is of great importance for users of complex production facilities, especially when such facilities operate at capacity. Following the requirements of environmental regulations and the increasing complexity of production systems over the last decades, the maintenance function evolved with the growth of technology [10]. The maintenance function is defined as a set of activities or tasks used to restore an item to a state in which it can perform its designated functions with minimum negative impact on the environment.

Eco-efficiency is a matter of concern at present and is receiving increasing attention in political, academic and business media. In general, this concept refers to the ability to create more goods and services with less impact on the environment and less consumption of natural resources, involving both economic and ecological level issues. Although organizations have embraced the rhetoric of sustainability in their speeches and external reports, little is known about the processes by which systems of management control contributed to greater integration of sustainability into organizational strategy.

Even showing some promise, it was argued that the challenge of accreditation is forcing companies essentially to adopt certifications (hence internalize certifications in daily practice), not just the adoption of certifications symbolic form [11]. For example, emphasize that the quality of maintenance and environmental impact are determined by the use of energy and resources, guided by environmental standards, as well as dependent on the policies adopted by the maintenance function and experience of workers. The adoption of environmental management systems is one of the most important elements of corporate sustainability in recent years. Although theoretically the importance of sustainable business models has become widely accepted in the literature, little is known about how managers deal with practical issues, such as differences in stakeholder interests. 
Presented as an introduction to the special volume of the 3rd International Workshop Advances in Cleaner Production, held in Sao Paulo, Brazil, in 2011, the theme of "Cleaner Production Initiatives and Challenges for a sustainable world", the content emphasizes recognition of the urgent and inevitable to make changes from unsustainable patterns of consumption for sustainable production need [12].

Sustainable development depends on more sustainable consumption and production patterns that respond to basic needs and bring a better quality of life while minimizing the use of natural resources so as not to jeopardize the needs of future generations [13].

Research suggests that the preconditions for the ISO 14001 certification motivations can be a good indicator of environmental strategy a company pursues. Moreover, the environmental strategy relates to the environmental performance results and operating company practices [14], i.e., the impact of proactive maintenance policy function in the productive system and hence into the environment are incorporating environmentally benign parameters in the three levels of the model input-processingoutput [15a], thus developing the Corporate Sustainability.

Corroborating, [16b] investigated that green teams are often considered in the literature as an essential for companies aiming to implement and improve the approaches and practices of environmental management factor.

The process Maintenance management can be divided into two parts: the definition of the strategy and strategy implementation. The first part, the definition of maintenance strategy, requires the definition of the tasks of maintenance function as an input, which derive directly from the business plan. This initial part of the process for the Management of Maintenance conditions for maintaining the success of an organization determines the effectiveness of subsequently implementing maintenance plans, schedules, controls and improvements.

The second part of the process, the implementation of the chosen strategy - has a different level of significance. Our ability to deal with the problem of deployment Maintenance Management (for example, our ability to secure adequate levels of qualification, preparation of suitable work, proper tools, and performance schedule) will allow us to minimize the cost of maintaining direct (work maintenance and other necessary resources). In that part of the process, we deal with the efficiency of our management, which should be less important. Efficiency is acting and producing with minimum waste, expense or unnecessary effort. Efficiency is then understood as the combination of the Operations and Maintenance Management with providing maintenance function equal to, or better for the same cost.

The third part is to create synergy in the association of operations and maintenance tasks, as it is important for the formulation of tasks, programming strategies and daily operations. However, maintenance should also be integrated throughout the manufacturing industry to better long-term benefits [17], as shown in Figure 1. 


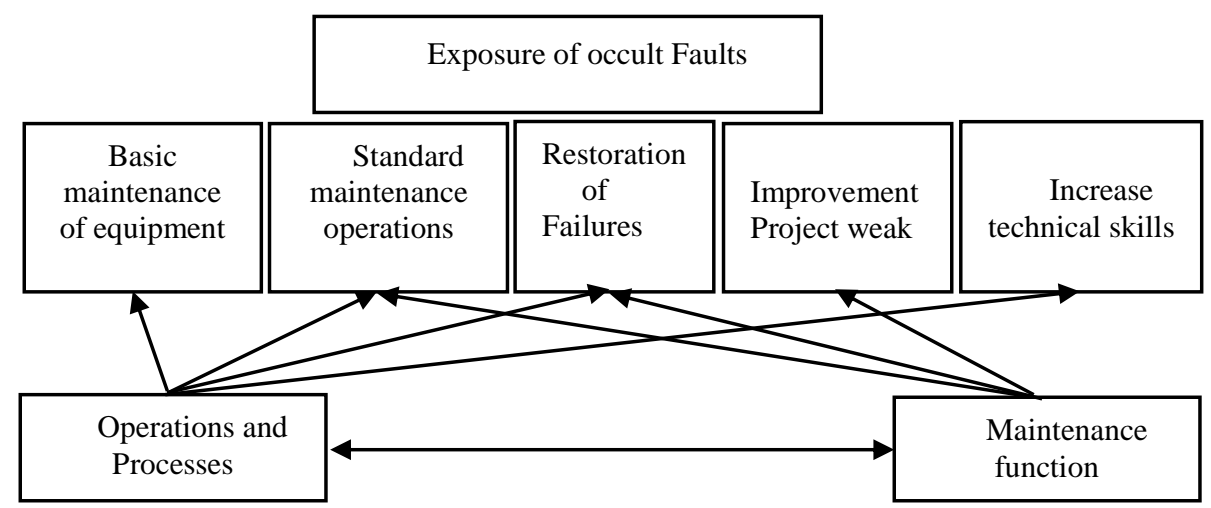

Font: Authors based on mapping the studied literature (2012)

Figure 1 - Relationship between operations and maintenance function

Therefore, for many authors, as [18, 19] the existing research on the prioritization of maintenance tasks have three major limitations: (1) long-term problem is considered as a short-term dynamics is ignored; (2) the relationship between production and maintenance functions, regarding the work order must be clear and (3) decisions are often made by heuristic rules.

Present a proposal for decision support in the short term for the prioritization of maintenance tasks function that can answer two important questions in relation to decision making: (1) On which machines the tasks of maintaining function without affecting the production system will be carried out? (2) Which task of the maintenance function should be performed first so improving obtains the highest throughput? [20]

The growing importance of the maintenance function of the industrial scenario and technological developments, especially the environmental advances of recent years have produced the development of modern maintenance strategies such as conditionbased maintenance and predictive maintenance [21].

A major research question guided the construction of this article. "What are the environmental attributes that drive proactive maintenance policy function for a minimal negative impact on the production system to the environment"? In answering this question, this paper contributes by providing objective evidence on how policies influence function of maintaining the potential outcomes of the production system. Furthermore, it provides new evidence on the potential economic, social and environmental benefits of efforts for the development of corporate sustainability.

The other sections of the paper are structured as follows: in section 2, a reflection on the term corporate sustainability, in section 3, a discussion of the methodology used in the study is presented, in section 4 , the results of a reflective analysis are reviewed, in 
section 5, a discussion of the main conclusions is provided. The article ends with conclusions and recommendations for future research in section 5.

\section{Methodology}

The paper presents an analytical reflection, based on the context of knowledge management, risk management, quality management, intra-organizational relationships through attributes associated with corporate sustainability. For reasons of theoretical essay, research was supported in mapping the primary references and analysis of different interpretations of sustainability reports from companies associated with the Ethos Institute (Brazil). To sort the search and consequently reply the research problem has been taken as the basis for taxonomy, who qualifies on three aspects:

(1) Regarding purposes - exploratory, because the main objective of the research is to clarify the influence of organizational factors and conceptual integration of the production system maintenance and function in the transfer of the Corporate Sustainability practices, with the understanding that there is little accumulated knowledge and systematized on that strategic integration; (2) As for the means - the research is classified as documents and literature, and (3) Answer the question: What are the environmental attributes that drive proactive maintenance policy function for a minimal negative impact on the production system to the environment? This research is justified by current and continuing need for theoretical and analytical reflection in the field of management of the production system integration and maintenance function.

\section{Results and Discussion}

This section presents a discussion of the results obtained in the research. Seeks to systematize and consolidate the literature review and theoretical and analytical reflection contextualized in order to expand the ongoing debate and deepen the nascent field of research. In light of these divergent views, while organizations recognize that environmental sustainability has implications for their competitive positions, companies are not clear about the details of implementation of environmental management practices. Although few environmental attributes that drive proactive maintenance policy function have been suggested in the literature mapping done, the article provides evidence needed for the use of these attributes in practice.

The possibility of benchmarking is particularly relevant for companies and organizations operating in the same sectors in the same country, especially if they are associated with some environmental institution with a mission to mobilize, sensitize and help companies manage their business in a socially responsible manner making 
them partners in building a sustainable and just society, for example, Institute Ethos (Brazil).

Despite the ongoing debate on the relationship between environmental management and financial performance, the survey allows us to observe inconsistency, making clear between companies, organizations and companies utopia. By identifying possible utopia between the binomial economic developments versus sustainable development are observed needs to work with these underlying conflicts in order to find fair and meaningful solutions to the problems facing us.

The assessment results help not only to choose an alternative design more suitable for a specific set of requirements and maintenance policies with minimal environmental impact, but also to assess the degree to which aspects of proactive maintenance policy can be incorporated into strategic planning. Furthermore, the processes of maintenance and environmentally benign procedures also have a greater role to play in reducing the environmental impact, in particular production systems. Facilitate the interaction of operations with maintenance systems through intuitive interfaces is a competitive advantage in terms of time and costs to industry is shown in Table 1. All the attributes shown in shaded rectangles can be met in the design phase of the product. The other attributes are those that can be maintained during the maintenance operation.

Table 1 - Attributes necessary to the practice of consistent policies and environmentally proactive maintenance strategies

\begin{tabular}{|c|c|c|}
\hline Environmental compatibility & Energy Efficiency & $\begin{array}{c}\text { Human health and safety } \\
\text { risks }\end{array}$ \\
\hline $\begin{array}{l}\text { Biodegradable Lubricants } \\
\text { and Cleaning agents }\end{array}$ & $\begin{array}{l}\text { Synthetic lubricants } \\
\text { derived from renewable } \\
\text { resources }\end{array}$ & Rules and regulations \\
\hline Prevention of leaks & Facility maintenance & $\begin{array}{l}\text { Adequate ventilation and } \\
\text { lighting }\end{array}$ \\
\hline $\begin{array}{l}\text { Adaptability during } \\
\text { maintenance }\end{array}$ & $\begin{array}{l}\text { Material and energy } \\
\text { efficient lubricants }\end{array}$ & $\begin{array}{c}\text { Use of non-toxic } \\
\text { solvents and lubricants }\end{array}$ \\
\hline Waste treatment policies & $\begin{array}{c}\text { Maintenance } \\
\text { management system }\end{array}$ & $\begin{array}{l}\text { Maintenance tasks } \\
\text { secure and easy }\end{array}$ \\
\hline Material with longevity & $\begin{array}{c}\text { Reduction of } \\
\text { unnecessary travel easy } \\
\text { transport }\end{array}$ & - \\
\hline $\begin{array}{l}\text { Minimal problems with } \\
\text { landfill }\end{array}$ & - & - \\
\hline
\end{tabular}

Font: Adapted from: [22b].

\section{Conclusions and recommendations}

In conclusion, the paper presents a new definition for the Maintenance function: the continuing development of systematic, coordinated, economic and implements through more proactive implementation of intra-organizational relationships in order to develop the optimization tasks in the three levels of the model input-processingoutput. As proposed in Figure 3, which shows the connections of continuous 
improvement with regard to the Maintenance function in the context of corporate sustainability. Finally, it is considered that the points analyzed were able to subsidize the authors of this article with regard to the response of the research question: "What are the environmental attributes that drive proactive maintenance policy function for a minimal negative impact to the production system environment "? In this sense, we believe that the research problem was answered.

Ultimately, we suggest a study on small businesses, because they have not received enough attention and are not represented in our study. Furthermore, the integration of production and maintenance system in the context of organizational culture and corporate sustainability will require further exploration in the context of a small business.

\section{References}

1. WCED - World Commission on Environment and Development (WCED). Our Common Future. Oxford University Press, Oxford, UK; 1987.

2. STEURER, R., LANGER, M.E., KONRAD, A., MARTINUZZI, A. Corporations, stakeholders and sustainable development I: a theoretical exploration of business-society relations. Journal of Business Ethics 61, 263-281; 2005.

3. GRAY, R. Is accounting for sustainability actually accounting for sustainability and how would we know? An exploration of narratives of organizations and the planet. Accounting, Organizations and Society 35, 47-62; 2010.

4. KOLK A. et al. CSR in China: analysis of domestic and foreign retailers' sustainability dimensions. Business Strategy and the Environment 19, 89-303; 2010.

5. HOPWOOD, A.; JEFFREY UNERMAN; JESSICA FRIES. Accounting for Sustainability: Practical insights. Earthscan. ISBN 978-1-849-71067-1; 2010.

6. GRI, 2010. Sustainability reporting guidelines. Available in: www.globalreportinginitiative.org. Access in: Janeiro; 2013.

7. YANG, C. L., LIN, S. P., CHAN, Y. H., SHEU, C. Mediated effect of environmental management on manufacturing competitiveness: an empirical study. International Journal of Production Economics 123 (1), 210-220; 2010.

8. XIAOLING ZHANG, LIYIN SHEN, YUZHE WU. Green strategy for gaining competitive advantage in housing development: a China study. Journal of Cleaner Production 19, 157-167; 2011.

9. CHARBEL JOSÉ CHIAPPETTA JABBOUR, ELICIANE MARIA DA SILVA, ELY LAUREANO PAIVA, FERNANDO CESAR ALMADA SANTOS. Environmental management in Brazil: is it a completely competitive priority? Journal of Cleaner Production $\mathrm{xxx}, 1-12 ; 2011$. 
10. ROSMAINI AHMAD, SHAHRUL KAMARUDDIN. An overview of time-based and condition-based maintenance in industrial application. Computers \& Industrial Engineering 63, 135-149; 2012.

11. PAVEL CASTKA, DANIEL PRAJOGO. The effect of pressure from secondary stakeholders on the internalization of ISO 14001. Journal of Cleaner Production (2013), doi: 10.1016/ j.jclepro.2012.12.034; 2013.

12. C. M. V. B. ALMEIDA, S. H. BONILLA, B. F. GIANNETTI, D. HUIGINGH. Cleaner Production initiatives and challenges for a sustainable world: na introduction to this special volume. Journal of Cleaner Production 47 (2013) 1-10; 2013.

13. IVETE DELAI, SÉRGIO TAKAHASHI. Corporate sustainability in emerging markets: insights from the practices reported by the Brazilian retailers. Journal of Cleaner Production 47 (2013) 211-221; 2013.

14. IURI GAVRONSKI, ELY L. PAIVA, RAFAEL TEIXEIRA, MARTA CLEIA FERREIRA DE ANDRADE. ISO 14001 certified plants in Brazil e taxonomy and practices. Journal of Cleaner Production 39, 32-41; 2013.

15. AJUKUMAR V. N., GANDHI O. P. Evaluation of green maintenance initiatives in design and development of mechanical systems using an integrated approach, Journal of Cleaner Production (2013), doi: 10.1016/j.jclepro.2013.01.010 (a); 2013.

16. CHARBEL JOSÉ CHIAPPETTA JABBOUR, FERNANDO CÉSAR ALMADA SANTOS, SERGIO AZEVEDO FONSECA, MARCELO SEIDO NAGANO. Green teams: understanding their roles in the environmental management of companies located in Brazil. Journal of Cleaner Production 46, 58-66; 2013(a).

17. H. YAMASHINA. Japanese manufacturing strategy competing with tigers. Business Strategy Review v.7, n. (2); 1996.

18. PINTELON, L.; GELDERS, L.; VANPUYVELDE, F. Maintenance Management, second ed. Acco Belgium, Leuven; 2000.

19. YANG, Z.; CHANG, Q.; DJURDJANOVIC, D.; NI, J.; LEE, J. Maintenance priority assignment utilizing on-line production information. Trans - action of ASME, Journal of Manufacturing Science and Engineering. v.129, p. 435 - 446; 2007.

20. MUCHIRI PETER; PINTELON, L.; G. LUDO; MARTIN, H. Development of maintenance function performance measurement framework and indicators. International Journal Production Economics. v. 131, p. 295 - 302; 2011.

21. LIN. LI; JUN NI. 2009. Short-term decision support system for maintenance task prioritization. Journal Production Economics. v. 121, p. $195-202 ; 2009$.

22. AJUKUMAR V. N., GANDHI O. P. Evaluation of green maintenance initiatives in design and development of mechanical systems using an integrated approach, Journal of Cleaner Production (2013), doi: 10.1016/j.jclepro.2013.01.010; 2013 (b). 